Physical Disabilities: Education and Related Services, 2014, 33(2), 16-35. doi: 10.14434/pders.v33i2.12965

(C) Division for Physical, Health and Multiple Disabilities

PDERS

ISSN: 2372-451X

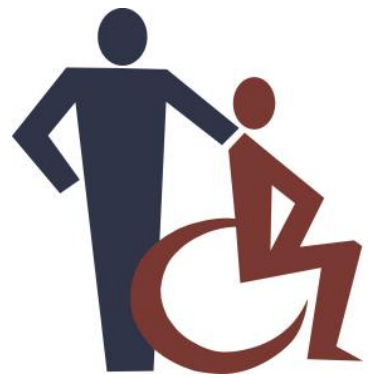

http://scholarworks.iu.edu/journals/index.php/pders/index

Article

\title{
SCHOOL EXPERIENCES OF AN ADOLESCENT WITH MEDICAL COMPLEXITIES INVOLVING INCONTINENCE
}

\section{Hollie Gabler Filce}

The University of Southern Mississippi

John B. Bishop

The University of Southern Mississippi

\begin{abstract}
The educational implications of chronic illnesses which involve incontinence are not well represented in the literature. The experiences of an adolescent with multiple complex illnesses, including incontinence, were explored via an intrinsic case study. Data were gathered from the adolescent, her mother, and teachers through interviews, email correspondence and school documentation over four months. Analytic memo writing was used to promote reflexivity and address researcher subjectivity. Three prominent themes emerged. There were excessive absences from school which were not always due to the physical implications of the student's incontinence. Some absences were attributed to fear of accidents at school or even fabricated by the student to avoid attendance. Next, an incomplete and inconsistent support and communication system was found which contributed to academic underachievement. Finally, the persona presented by the student led to inaccurate assumptions by school personnel and sometimes her mother regarding her ability to cope with her condition.
\end{abstract}

Keywords: qualitative; chronic illness; adolescents; incontinence 


\section{Introduction}

It has been estimated that over 11 million children (15.1\%) in the United States have special healthcare needs (U.S. Department of Health and Human Services, 2013). Multiple, complex medical diagnoses make it difficult for professionals to adequately understand each condition, to determine how each condition impacts the child individually and collectively, or to identify how to best support the child across environments (Cohen et al., 2011). The needs of children with medical complexities, including those with rare disorders, are often underrepresented in the research due to the difficulty in attaining large enough sample sizes. These children are diverse in their specific diagnoses, and require study and understanding of their functional limitations across settings (Cohen et al., 2011).

VACTERL association is a medically complex, rare condition occurring in 1:10,000- 40,000 live births (Solomon, 2011). By definition, those with VACTERL association have at least three congenital malformations from among the following seven major body systems: vertebral defects (V), absence or abnormal narrowing of the anal systems (anal atresia, A), cardiac defects (C), abnormal openings in the trachea or esophagus (tracheo-esophageal fistula, TE), renal anomalies (R), and limb abnormalities (L). Individuals with VACTERL association do not typically have concurrent cognitive or neurological impairments (Solomon, 2011). It is estimated that anywhere between 55 and $90 \%$ of individuals with VACTERL association have anal atresia, which impacts bowel continence, and 50-80\% have renal anomalies, which impacts urinary continence (Botto, 1997; Rittler, Paz, \& Castilla, 1996; Solomon et al., 2010; Solomon, 2011; Weaver, Mapstone, \& $\mathrm{Yu}, 1986)$. As with any congenital condition, the level of impairment varies widely from individual to individual, and functional limitations are difficult to predict on the basis of diagnosis alone.

In addition to physical well-being, we are also concerned with the educational well-being of children with chronic illness. School attendance is a strong predictor of academic achievement for students in general (Balfanz \& Byrnes, 2012; Carroll, 2010) and for students with chronic illnesses in particular (Caldwell et al., 1997; Sato et al., 2007; Wodrich \& Cunningham, 2008). When a child has a chronic illness that manifests in incontinence, the physical impact of illness often necessitates absences from school for hospitalizations, treatments, therapies, and recovery time. While studies have shown students with chronic illness miss school more frequently than their peers (Caldwell et al., 1997; Sato et al., 2007; Shapiro et al., 1995; Wodrich \& Cunningham, 2008), little has been reported regarding absenteeism for children with incontinence related to VACTERL association. Filce and LaVergne's study (2011) showed a significantly higher absenteeism rate for children with bowel and/or bladder dysfunction (22.5\% missed more than 11 days per year) as compared to the general population (6\%) (Bloom, Cohen, \& Freeman, 2011).

While all students with chronic illnesses are eligible for educational accommodations under Section 504 of the Rehabilitation Act of 1973, the impact of their illness sometimes makes them also eligible for special education services under the Individuals with Disabilities Education Act (IDEA, 1997). Both of these laws require schools to develop educational plans (504 Plans or Individualized Education Plans [IEP]) to address the needs of these students during the school day. Additionally, professional organizations recommend the development of an Individualized Healthcare Plan (IHP) to specifically address the medical needs of students with chronic illnesses 
(American School Health Association, 2002; National Association of School Nurses, 2013). Despite these mandates, many students with chronic illnesses impacting continence often do not have formal structures of support in place during the school day. Filce and LaVergne (2011) studied educational plans specifically for this population and noted that, despite their medical complexity, almost a third (31.4\%) had never had any type of educational support plan. Additionally, despite their medical needs, only $8.8 \%$ had ever had an IHP as a standalone document or as a part of a 504 Plan or IEP.

To further complicate the school experience for students with chronic illnesses, psychological and emotional factors are often inextricable from an adolescent's illness and physical conditions. Anxiety in various forms is linked to school attendance among children with chronic illness (Fereday, Kimpton, \& Oster, 2011; Lundblad, Berg, \& Hellström, 2007; Weaver \& Dobson, 2008; Williams, Chambers, Logan, \& Robinson, 1996). For children with incontinence, a negative social stigma is reported to increase anxiety (Boyt, 2005; Butler \& Swithinbank, 2007; Dowbiggin, 2009; Gray, Blackinton, \& White, 2006; Lundbladet al., 2007; Lundblad, Hellström, \& Berg, 2010; Sureshkumar, Bower, Craig, \& Knight, 2003; Weaver \& Dobson, 2008; Williams et al., 1996). Moreover, fears related to embarrassment, bullying, and need for privacy contribute to school attendance, often preventing children with incontinence and parents from telling teachers about the child's condition (Best, 2005; Fereday et al., 2011; Lopez, Mullins, WolfeChristensen, \& Bourdeau, 2008; Lundblad et al., 2007; Lundblad et al., 2010).

While some literature is available discussing overall quality of life for children with incontinence due to a chronic illness (Bai et al., 2000; Baker-Towell \& Towell, 2003; Brandt et al., 2007; Fasten, 2000; Nisell, Öjmyr-Joelsson, Frenckner, Rydelius, \& Christensson, 2008; Funakosi et al., 2005; Grano, Aminoff, Lucidi, \& Violani, 2012; Luscombe, 2000; Mills, 2007; Mukherjee, McCauley, Hanford, Aalsma, \& Anderson, 2007; Yi et al., 2009), there is less available focusing on the needs of these children at school (Butler \& Swithinbank, 2007; Fereday et al., 2011; Filce \& LaVergne, 2011; Lundblad et al., 2007; Weaver \& Dobson, 2008; Williams et al., 1996; Lundblad, Hellström, \& Berg, 2010). Still, school professionals are charged with understanding complex medical, emotional, and academic needs of these children in order to provide appropriate accommodations and supports.

This intrinsic case study explored the educational experiences of an adolescent girl, Emily (pseudonym), with VACTERL association and incontinence. Emily's experience was significant, as the unique and complex nature of her conditions challenged the typical processes of schools as professional service providers sought to provide educational services. Making the case even more interesting was the sensitive nature of Emily's incontinence, which challenged Emily not only physically but emotionally. Emily's willingness to share openly provided detailed and honest descriptions of her school experiences as well as valuable insight to our primary research question: How does an adolescent with a medically complex condition involving incontinence navigate her school experience? Our research had two purposes: (1) to provide a detailed account of Emily's schooling from multiple data sources, and (2) to generate a depth of understanding about this individual case that may lead to insight and empathy for other students who have chronic illnesses including incontinence. 


\section{Methods}

\section{Participants}

Emily, a 15-year-old Caucasian female diagnosed with VACTERL association at birth, was a sophomore at a public high school in a rural, Southeastern town. Of the seven body systems affected by VACTERL association which were described earlier, Emily had defects with four. She had vertebral defects (V); specifically, tissues in her spinal column had become attached to her spinal vertebrae which prevented her spinal cord from moving within her vertebrae normally. This tethering of the spinal cord restricts movement and can cause neurological and motor impairments. Her spinal cord had been surgically released in the past, but some motor deficits remained. Emily also was born with anal atresia (A), specifically cloacal exstrophy in which she was born with her bowel, bladder, and reproductive organs on the outside of her abdomen. These systems were moved into her abdominal cavity at birth. Emily's renal anomalies (R) included a solitary left kidney. Finally, her limb abnormalities (L) were a webbed right leg which was amputated during the fall of her freshman year in high school. Her cloacal exstrophy and solitary left kidney resulted in a lack of continence for both urine and stool. Emily had a Mitrofanoff, which is an opening surgically created using the appendix to create a conduit between the surface of the abdomen and the bladder through which a catheter can be inserted to empty urine.

When Emily was younger, her fecal incontinence was managed through the use of a Malone Antegrade Continence Enema (or MACE), which is an opening from the abdomen to the colon through which a solution is injected into the top of the colon flushing stool out through the anus. However, Emily's MACE was removed after a bowel obstruction and she used rectal enemas to empty her bowels daily at the time of data collection. During the bowel obstruction, Emily reacted negatively to an antibiotic, causing permanent, bi-lateral hearing loss. She wore hearing aids in both ears.

Emily lived with her mother, stepfather and three step-siblings, all aged four and under. She attended public school until the middle of her fourth grade year. During that time, Emily received accommodations via a 504 Plan which included nursing services to assist her with toileting issues. However, because of what Emily's mother described both as a lack of support at school and her personal desire for homeschool, she began homeschooling Emily midway through fourth grade. Emily had no diagnosed intellectual or learning disability, nor was she considered behind academically. This proved an important contextual piece to Emily's overall academic history and no evidence was found that Emily struggled intellectually with school.

After four and a half years of homeschooling, and at Emily's request, she returned to public school to begin her freshman year of high school. A 504 Plan was developed and included accommodations such as a flexible restroom schedule, limited physical education requirements, preferential seating, written directions for all assignments, extended time for testing (with breaks), an extra set of textbooks at home, use of elevators, and the use of crutches. Both her mother and teachers indicated Emily received "flexible homebound instruction" as an accommodation, but her 504 Plan did not refer to this in any written form. According to both her mother and teachers, "flexible homebound" referred to Emily's option to miss school "whenever 
needed" without being subject to truancy regulations. Emily had never received special education services.

\section{Intrinsic Single-Case Study Design}

A single-case study (Merriam, 1998; Stake, 1995) allowed us in-depth, descriptive research processes (Miles, Huberman, \& Saldaña, 2014; Yin, 2014) that guided our methodology towards understanding as much as possible about the particularities of Emily's schooling within her reallife context. Variation as to what defines a case study exists across a spectrum of theoretical and methodological conceptualizations (Baxter \& Jack, 2008; Creswell, 2013; Hancock \& Algozzine, 2011; Stake, 1995). However, one distinguishing feature of all case study research involves "bounding" the case by both a specific temporal reference indicating the beginning and ending of the investigation along with a predefined contextual boundary. This case study was designed as an intrinsic case study, exploring a particular case because of the interesting nature of the case itself (Stake, 1995). Data collection began in September 2013 with face-to-face interviews, follow-up emails, and a final follow-up telephone interview four months later. This timeframe did not include our research design, participant recruitment, or related work after data collection. The timeframe was selected to mirror a contemporary high school semester and was a meaningful length for our defined contexts of school settings and experiences.

\section{Researcher Reflexivity}

As the parent of a child who shares some of Emily's medical conditions, our lead researcher was personally and professionally invested in understanding school experiences of students with incontinence. As a research team, we noted both the benefits and challenges this experiential knowledge presented for our research. We gained insight from this researcher's experience with parent-to-parent support groups for children with congenital anorectal malformations, consultation for affected children and their families regarding school accommodations, work as a special educator in public school, and scholarship as a university faculty member engaged in research regarding students with medically complex conditions. Though our case study was designed to be exploratory and descriptive, our research process was informed by academic assertions and personal understandings. For example, we chose to include a modified process of pattern matching (Yin, 2014), analyzing data against both existing theories in scholarly literature and direct experiential knowledge. Throughout the data collection period, we engaged in analytic memo writing to check for researcher subjectivity. The process of interviewing was coupled with frequent co-researcher data discussion meetings. The two perspectives represented on the research team (one with experience with the given conditions and one without) proved invaluable, providing increased capacity for seeking divergent information during data analysis.

\section{Data Collection}

In-depth interviews. We conducted in-depth interviews (Hancock \& Algozzine, 2011; Lichtman, 2013; Seidman, 2011; Yin, 2014) using open-ended questions intended to maximize our participants' perspectives. Interviews were conducted with Emily, her mother, and her teachers face-to-face in September and by phone in December. Each initial interview lasted approximately 60-90 minutes, with subsequent phone interviews lasting 30-60 minutes. The style 
of interviews varied between conversational (as relevant researcher experiences and motives were made transparent) and phenomenological (with efforts to place maximum value on the participant's words). This was done to maximize the distinct language and personal stories of the primary participant's experiences. Ultimately, the inherently collaborative role the researcher plays in data production during interviews (Fontana \& Frey, 2008) was heightened in the process through shared empathy, mainly with Emily's mother. As such, it is important to note that the lead researcher conducted all interviews and gained "insider" status with Emily and her mother. Listening with empathetic insight to a wide range of feelings and experiences provided ways to explore topics during interviews with more opportunities for elaboration. However, this furthered the methodological need to use multiple data sources and give explicit attention to ways interview data were co-constructed and analyzed.

Follow-up emails. Email exchanges occurred at the end of September, October, and November. These email communications between the lead researcher and participants served to verify certain participant statements, and to gather more frequent attendance and academic progress data between the initial face-to-face interviews in September and the final phone interview in December. For example, the researcher used email to elicit information from participants about school absences and the communication between Emily, her mother and her teachers regarding those absences. While Emily's mother indicated during face-to-face interviews that teachers would call or send emails about makeup work, this communication did not occur according to the follow-up email exchanges. When asking about missed work being made up, Emily once indicated in an email that no work was sent home. The same week, teachers reported that Emily did not ask for missed work upon returning to school. This prompted the researcher to ask Emily, her mother, and her teachers whose "job" it was to make sure Emily knew what she missed in class. Both Emily and her mother responded, "Teachers," while all three teachers responded, "Emily." This exchange illustrates a lack of common understanding of the expectations and processes for ensuring content and work missed were addressed.

In addition, email was utilized to clarify certain interview statements. Emily's mother, for instance, stated she believed Emily sometimes "pretended" to need to stay home because she (the mother) was sick. When asked to elaborate, Emily's mother wrote, "I mainly felt that Emily wanted to take care of me because she would tell me to rest and she would take care of the little kids." The email data supplemented face-to-face interviews by providing further insight to existing data, in this case raising important questions about absenteeism and Emily's role at home.

Analytic memos. Writing analytic memos provided a means to be both reflective about the data collection and analysis methods, as well as more systematic in our observations of the nature of Emily's contexts and experiences. Researcher reflections regarding things reported by the various adults interviewed augmented the interview transcripts. Initially, pattern matching against existing propositions focused our initial coding choices. Our work with memo writing, however, evolved with more exploratory depth, particularly as we saw connections between contextual factors and behaviors Emily used to make her way through this high school year. Analytic memo writing aided in the discovery of "little conceptual epiphanies" (Miles et al., 2014) and simultaneously challenged the stated experiences of the various participants when examined through our own beliefs and values. 
School documents. Much like the weekly email exchanges, school documents were reviewed to accompany and provide further insight to existing interview data. Specifically, accommodation plans, school report cards, and absentee records helped establish a more holistic view of the data. Emily's 504 Plan brought to our attention the absence of school documented information, specifically records addressing Emily's incontinence. Coupled with teacher interviews and email exchanges, Emily's 504 Plan documents raised questions about the school's understanding of Emily's medical conditions. Absentee records and report cards were also used to establish a more comprehensive view of Emily's attendance patterns and academic history.

\section{Data Analysis}

We individually coded interview transcripts through a variety of analytic lenses that focused on data holistically, emotionally, through actions, and through the "in vivo" language of participants (Saldaña, 2013). We then congregated salient codes into categorical groups and met to discuss coding and grouping decisions and the differences in our responses. Other analysis tasks were distinctively separate; one of us traveled via plane for participant and school data collection visitations and conducted all interviews while the other examined the interview process raising questions about reflexivity and interactions and their impact on data. Links, including prominent chains of evidence across data sources, and noteworthy diverging or contradicting data were examined and discussed collaboratively using interview categorization as foundational reference points. Beyond discussion, visually organizing and displaying data graphically (Merriam, 1998; Miles et al., 2014) helped move corroborating categorical evidence toward thematic development.

\section{Thematic Results}

Three themes emerged from the data and were broadly classified as excessive absenteeism, unclear and inconsistent support, and incongruent outward and actual coping with the physical and emotional ramifications of the illness. Multiple sources showed Emily missed an inordinate amount of school on a regular basis. Moreover, there was a lack of understanding by the teachers as to the reasons for those absences. Finally, decision-making as to if Emily should miss school was confounded by the unpredictable nature of Emily's incontinence, fears associated with potential accidents at school, and reported instances of Emily sometimes taking advantage of her condition to avoid school. A second theme centered on the lack of specificity and inconsistent support provided by school personnel. This included the presence, nature, and execution of formal support plans and communication systems at school. The ways Emily and those around perceived that she handled the implications of her condition at school emerged as a final theme. Inconsistent expectations and actions were reported, further illustrating the complexities imposed by chronic illness on adolescents at school.

There were excessive absences from school which were not always due to the physical implications of Emily's incontinence. Some absences were attributed to fear of accidents at school or even fabricated by the student to avoid attendance. The literature suggests that children with chronic illness miss more school than do their peers without illnesses (Caldwell et al., 1997; Sato et al., 2007; Shapiro et al., 1995; Wodrich \& Cunningham, 2008). During initial interviews, Emily and her mother reported that Emily might miss anywhere from 1-3 days of school each week if she was not feeling well. However, during the four months during which attendance data 
were collected, there were at least two weeks where Emily missed every day, and no week passed in which she missed fewer than two days of school. Teachers reported absences from school ranging from a couple of days to weeks at a time. All five data sources converged highlighting Emily's absenteeism.

While absenteeism due to chronic illness is well supported in the literature, the degree of absenteeism for Emily was significantly higher than suggested by this literature and was not always reported to be a direct function of her illnesses or incontinence. Many times both Emily and her mother reported absences were based in a feeling that Emily would have an accident that day. Sometimes these feelings were shown to be justified and sometimes they were not. When asked why Emily missed school, her mother stated, "If we don't get a good cleanout...she's having bowel accidents. I'm not gonna send her to school... I've told them when she's home sick, she's not coughing, throwing up, laying in the bed with a fever. She's able to do things. She's just not socially acceptable." When asked about the frequency of accidents leading to absences, both Emily and her mother indicated Emily often misses school when her bowel management routine does not work well and she "knows" she will have accidents that day. Both indicated she rarely had accidents at school now. When asked if she ever thought that Emily stayed home when she really could have gone to school, Emily's mother said, "I think she stays home sometimes erring on the side of caution...I can understand why... I mean, how embarrassing is that gonna be? Trust me, when she has an accident, you know it."

What was not altogether expected was the amount of decision-making power Emily had regarding whether or not to attend or remain at school on any given day. Emily not only stayed home from school when she was having frequent accidents, but also when she anticipated having accidents at school. When questioned as to how she knew she was going to have a "bad day," both Emily and her mother indicated that Emily "knew her body" and had come to be able to anticipate that she would have an accident later in the day. The interview with Emily, however, yielded a candid admission that she sometimes used her illness as an excuse to not attend school on certain days when she was in reality physically able to attend. Emily said, "Lordy, did I do it last year...I did not like my classes last year and I did not like getting up early last year, but now I'm used to it." When we followed up with Emily's mother regarding the times that Emily missed school unnecessarily, she said, "She took advantage of it a lot when I was sick last year...I have to wonder if she didn't stay home just because she felt like she needed to take care of everybody. I don't think she does it as much as she did."

In contrast to absences being ascribed to incontinence by both Emily and her mother, her teachers mainly believed her lack of attendance stemmed from her more visible conditions (primarily her amputation). The only teacher that spoke about Emily's incontinence attributed it to the stress of her amputation. "That was another period of a lot of absences where she was just so stressed out she just couldn't control her bladder or control any type of function with it." This misattribution or lack of understanding is evident throughout follow-up email and phone correspondences, and is consistent with literature that suggests the topic of incontinence is not discussed frequently among parents and school personnel (Best, 2005; Lundblad et al., 2010). While both Emily and her mother expressed they were open with school staff about her incontinence, the lack of awareness by teachers expressed in the interviews suggested otherwise. 
These absences resulted in Emily missing large amounts of learning time. The impact of this missed time is further discussed in the following section.

We also found an incomplete and inconsistent support and communication system at school which contributed to academic underachievement. Emily was born with multiple, complex health conditions that required the attention and support of both her mother and professionals from birth. During initial interviews, Emily's mother described Emily's elementary school experiences as less than ideal, which contributed to her decision to homeschool Emily midway through fourth grade. According to Emily's mother, despite the elementary school's insistence on having the school nurse provide support to Emily relating to her catheterization and accidents, there was little follow-through. Her mother said, "At that time she was little enough that she needed help to clean up, and the nurses were not cleaning her up. They were letting her walk around school all day [after having an accident]. We were very unhappy with that. That was a big part of the homeschooling decision."

When Emily decided to return to public school as a freshman, her mother and the school once again developed a 504 Plan to outline Emily's support needs. When analyzing plans from Emily's freshman and sophomore years during our data collection process, the accommodations listed were very generic - extended time on assignments, waived physical education requirement, use of the school elevator, and exemption from the attendance policy. There was no mention of physical or mental health-related services or supports (including the services of a school nurse). When asked about this, Emily's mother indicated that Emily was fully self-sufficient in taking care of her needs at school and they did not need the nurse's assistance. Moreover, when asked about Emily's 504 Plan, only one of the three teachers interviewed was confident that she had seen it.

All adults interviewed indicated Emily was on "flexible" or "partial homebound" services. However, when reviewing her educational records, neither 504 Plan (current or previous year) indicated this support. While reportedly intended to support Emily through her frequent absences, the label of "flexible homebound" seemed to cause confusion, as it had never been applied in the past. When asked to define "flexible homebound," Emily's mother and teachers all said that there was a homebound teacher who could go to Emily's house as needed to work with her on assignments when she missed school. One teacher explained, "She had what we call a flexible homebound. It was like when she needed it, she would go on homebound. I think maybe that could have contributed to the confusion. Usually, when a child is given homebound, it's for six months to a year." No one interviewed could provide more specific operating parameters for this service, nor was it outlined in any school records.

Teachers were also unclear as to who was responsible for monitoring Emily's absences and missed assignments, or how to send/receive those missed assignments. These tasks were also not outlined in the 504 Plan, and teachers indicated keeping up with missed assignments was difficult on a day-to-day basis. As one teacher said, "I was so confused...I was told to make a list of - any day she wasn't there, just have a sheet of paper, write down whatever we did that day, that way when she did come I could give her the list. That's what I did. The problem we ran into with Emily was that when she did come to school, I would say, "Well, here's the list of stuff," and she would say, "Well, I'll get it from [the homebound teacher]." There was also a lack of 
consistency in the length of time Emily was given to make up missed work. All teachers reported that three days was standard for all students at their school, but that Emily could take longer ranging from a week all the way to the end of the 9-week reporting period.

In addition to the logistical complexities of tracking missed assignments, teachers expressed uncertainty about how much work they should expect Emily to make up when she was absent. Emily did not make up all work in the same manner as the other students, with assignments often shortened or changed. Decisions to shorten, change, or waive the assignment were made on a day-to-day basis by the teacher, not in accordance with a pre-determined plan or schedule. Both teachers of Carnegie unit courses indicated significant concern for the content Emily missed while absent. One teacher said, "I mean there's going to be little things here and there that she's just not going to understand because she missed out on those-even if it's a small lesson, it's going to build on itself eventually."

Emily initially received a failing grade in one course, primarily because of incomplete work resulting from absences. While this teacher initially didn't believe Emily mastered the content needed to pass the course, Emily's passing score on the state-mandated End of Course Assessment helped persuade the teacher to allow Emily to make up work and receive a passing grade. Emily's overall educational progress as documented by her grades and is aligned with literature suggesting that gaps in knowledge can be attributed to absenteeism (Caldwell et al., 1997; Clay, 2004). While Emily passed all other courses, the teachers interviewed all agreed that she did not have the depth of understanding of the course content that other students had. They indicated that because she was absent so much, they changed and reduced the content significantly, perhaps altering the fundamental nature of the courses. This discrepancy in what the teachers felt Emily mastered as compared to what other students mastered was not clearly communicated to Emily or her mother, both of whom felt she had mastered the content based on her grades on her report cards. As there was no other way to convey progress or lack thereof, this is an understandable assumption on the part of Emily and her mother.

Emily's mother and teachers universally agreed that home-school communication was highly inconsistent, when present at all. Efforts to consistently provide needed accommodations and to hold Emily accountable for academic tasks were not sufficient. While there was a meeting at the beginning of each school year to develop a written 504 Plan, these plans did not outline communication strategies that would be used. In fact, Emily's mother only reported meeting with teachers during Open House other than during the 504 Plan meeting at the beginning of the year. While Emily's mother indicated she could call or email teachers when needed, this was only reported being done very late in the year after it was impossible to remediate problems. In hindsight, the teacher of the course Emily initially failed the previous year remarked on the lack of a systematic, clear approach for dealing with Emily's absences, and subsequently, her missed content. "I feel like we could've come up with a game plan because her mother is very nice and she's very dedicated to Emily's education...I really just feel like communication in the beginning would have solved all those problems." While teachers expressed great concern about missed content, Emily and her mother seemed less concerned. Both indicated that teachers let Emily know what was missed and she turned in most makeup work as assigned. Likewise, both Emily and her mother seemed to believe that Emily's absenteeism did not negatively impact her 
educationally, as her grades were adequate for the most part. The only time in which they were dissatisfied with her grades was when her final report card indicated a course failed for the year. Finally, the outward persona presented by Emily often led to inaccurate assumptions by school personnel and sometimes her mother regarding her ability to cope with her condition. Throughout the interviews, there were incongruent perceptions of Emily's ability to cope with her illness. On the one hand, all interviewed (including Emily) shared on more than one occasion that she appeared to handle her illness remarkably well. However, some stories shared seemed to suggest otherwise, such as instances where Emily cried about her condition or her peers' reactions to her. Her mother reported concern for Emily after she disclosed she had been cutting herself, which prompted her mother to secure psychological counseling for Emily. Both through the interviews themselves and the reports of all interviewed, Emily portrayed confidence and positive coping strategies outwardly. However, when probed, she admitted keeping much to herself or only sharing with her friends made through a summer program for children with incontinence. The idea of being "normal" was also reported by multiple participants.

While all teachers interviewed stressed how much Emily has had to endure regarding her illness, they did not seem to have a deep understanding of the academic and emotional implications of her illness, particularly her incontinence. Teachers suggested Emily's persona at school was one of outward confidence. One teacher said, "[Emily] doesn't have that self-consciousness that most teenagers have, which is kind of surprising. She really has exceeded what I probably would've expected from a kid with the extent of disability that she seems to have. She hides it and just doesn't seem bothered by it." When asked why she was surprised, her teacher responded, "I would think for most kids if you're out of school half the time, socially you would feel out of place... Those kinds of just self-conscious issues that most kids have, even without any kind of a disability. She just doesn't seem to have that." Later in an email, the same teacher said that Emily "seems to have pretty strong self-esteem. To me, she does not seem self-conscious about her physical disability, and she seems determined to do everything that everyone else can do."

Emily's mother reinforced a positive attitude and repeated what she told Emily in an interview, "You have nothing to be ashamed of. There is not a single thing wrong with you that you need to be ashamed of. You're different. So what? Everybody's different somehow." Emily's mother stated repeatedly that Emily handled her condition (including incontinence) and its ramifications just fine. When asked about her current feelings, Emily's mother spoke primarily about Emily's amputation, not her incontinence. She said, "This thing with her leg has been the most bizarre experience for me....She's like, 'People stare at me.' I'm like, 'You don't think they stare at you? Well, you have no leg.' ... Of course, there are kids who stare at her. Well, what are you gonna do? I can't make everybody stop staring. I have to wonder, too, if it's more of a she perceives more stares than she actually gets. You know how it is."

Emily also spoke of calling attention to herself at school because of her time spent catheterizing herself via her Mitrofanoff for her urinary incontinence, "All the kids are like, 'Oh, why do you go to the office?' I did last year...I'm like, wait, wait, wait. Last year I drew attention to myself while walking to the office when I could've just gone to the bathroom like a normal person. 'Emily, you're an idiot.' This year I'm goin' to the bathroom like normal." This issue of normalcy was pervasive throughout the interview data, and marked in many ways an outward portrayal of resilience by Emily regarding her illness. Regarding a boyfriend, Emily shared, "We started 
going out. Then one day he asked me out of the blue, 'When will you be normal?' That made me mad. That made Maria [her best friend] mad. She kind of cussed him out a little bit. It was all kinds of drama and I just said, 'I'm done. Done. Done. Done.' So I broke up with him and I'm actually really happy about that. When I say really happy about that, I mean — and he'll still send me text messages saying, 'You look so beautiful.' I'm like, 'Stop it.'”

Overall, remarks made by Emily, her mother and her teachers, along with our research interactions with Emily, she maintained an outward identity ostensibly different from the literature that linked anxiety, depression, and emotional distress with chronic illness and, particularly, incontinence (Baker-Towell \& Towell, 2003; Funakosi et al., 2005; Luscombe, 2000; Mills, 2007; Mukherjee et al., 2007; Stjernqvist \& Kockum, 1999; Yi et al., 2009). Emily even minimized statements of self-consciousness, downplaying that version of self after expressing "I can be myself at Rally [a camp for adolescents with bowel and/or bladder incontinence], like completely myself. I can do that at school, just not-it's kind of the censored version of myself, if that makes any sense at all." When asked, "What do you censor at school that you don't censor at Rally?," Emily replied, "That wasn't the right word.... I basically am myself at Rally and at school except they don't have the medical problems. That's about it."

When interviewing Emily's mother as to if Emily ever mentioned anything about feeling different, Emily's mother responded with a statement which began very positively, but then gave a disturbing description of behavior in conflict with previous statements. She said, "I think she's well adjusted. I think she's pretty happy. Obviously, there are some self-esteem issues. She's just started on an antidepressant. We had some cutting going on. It's hard enough to be a teenage girl; it's super hard to be a teenage girl with medical issues." When probed about the selfmutilation, Emily's mother stated that a summer camp for teenagers with incontinence allowed Emily to explore those feelings with others who could empathize. Her mother recognized this was something for which they needed professional help and immediately began taking Emily to see a counselor. While the disclosure spoke to Emily's bond with her mother, along with the supportive environments of Rally and summer camps in which Emily could be herself completely, the self-destructive behavior starkly contrasts the façade Emily, her mother, and her teachers portrayed. The somewhat dismissive way information regarding Emily's need for professional counseling prompted a deeper examination into issues seemingly glossed in previous interviews.

\section{Discussion}

The three prominent themes presented are interwoven and raise questions about absenteeism as a potential indicator that speaks to the need for school support structures that address students with medical complexities through a more holistic lens. When the illness manifests in sensitive and potentially stigmatizing ways, finding the appropriate support is complicated, evidenced in Emily's and her mother's comments that school nurse care was unneeded. How to appropriately respond to Emily's absenteeism seems to be a central issue, as meeting the needs of students with chronic illness at school is in and of itself a difficult task complicated by the incredible variation in the needs of students with complex medical challenges. 
The fact that Emily missed school was not an unexpected finding, but the frequency of those absences as well as the amount of decision-making power Emily had regarding school attendance was somewhat unexpected. When probed as to the underlying rationale for erring on the side of caution when deciding whether or not to attend school, both Emily and her mother expressed fear of the social and emotional ramifications of having an accident at school. This aligns with data from previous studies suggesting parents tend to be overly cautious in cases where the potential for their child to experience embarrassment exists (Boyt, 2005; Gray et al., 2006; Lundblad et al., 2010; Weaver \& Dobson, 2008; Williams et al., 1996). As adolescents mature, they become both more private about and more responsible for their physical health. During adolescence, it is often difficult for parents to ascertain if they should be pushed to attend school or if the adolescent's judgment regarding attendance should be honored. Emily's reported experiences further validate what has been reported about school attendance and incontinenceit is frequently difficult for parents and children to differentiate between physiological symptoms of incontinence and anxiety. As the physical symptoms are often similar (i.e., stomach discomfort), the process of discerning whether school attendance is a wise choice, or even a feasible one is made more challenging (Wheaton, Berman, Franklin, \& Abramowitz, 2010). The admission that Emily sometimes was untruthful about her ability to attend school confounds the issue of school attendance. Parents must not only contend with the physical and social implications of accidents, and the fears relating to accidents, but also the real lure of skipping a day of school using incontinence as an excuse. These complicated, and often unobservable underlying factors made it difficult for Emily, her mother, and her teachers to determine how much Emily could realistically be expected to attend school. It also made attending to the barriers to attendance difficult, with potential causes being physical, emotional, or a combination of both.

Warranted or not, Emily's excessive absences from school had educational ramifications. The lack of a viable educational support plan and specific plans for frequent home-school communication resulted in what everyone agreed to be academic underachievement for Emily. There is much support in the literature (both professional guidelines and research) for formal supports at school (American School Health Association, 2002; Best, 2005; Clay, 2004; Filce \& LaVergne, 2011; National Association of School Nurses, 2013; Shapiro et al., 1995) as these children are at risk for underachievement (Best, 2005; Clay, 2004; Wodrich \& Cunningham, 2008). The lack of awareness of Emily's 504 Plan, the low level of individualization in this plan, the ambiguity of processes and responsibilities, and an overall absence of regular communication all contributed to Emily's lackluster performance at school. This manifested in mediocre and sometimes failing grades, drastically altered academic requirements which may or may not ensure adequate content preparation, and her teachers' professional judgment that overall her academic experiences are compromised by inevitable gaps in knowledge from absences.

When communication between school and home is inadequate, a similar question becomes apparent. How do schools address and adhere to written accommodation plans that are not specific enough for the unique needs of students with medical complexities? This question is further confounded when, as in Emily's case, teachers indicated lack of knowledge about her incontinence and its relationship to her absenteeism. While this was conveyed during the 504 planning meeting, a lack of working knowledge of this document by most teachers minimized the critical need for communication and support at school. The assumption that teachers were 
aware of her conditions and needs on the part of Emily's mother, based on the 504 planning meeting, coupled with the need for privacy as to the day to day realities of incontinence, seemed to minimalize the need for support. In Emily's case, a breakdown at all school levels seemed evident, noticeable both by the lack of an individualized, comprehensive 504 Plan document and further by the report that only one teacher had even viewed it.

The image presented to others as a strong, well-adjusted adolescent is problematic on several levels. Despite Emily's insistence that she did not need assistance at school from school health professionals, the probability that her condition and associated anxiety necessitated such frequent absences presented somewhat of a conundrum. It was surprising that there was no mention of collaborative working relationships with school health professionals, even if only in monitoring roles, in Emily's daily life. While this seemed to be Emily's preference, the self-reported evidence of her astute ability to maneuver around attendance policies coupled with her history of self-mutilation seemed to suggest otherwise.

\section{Limitations}

A single-case study is limited in its ability to produce generalizable findings. The exploratory and descriptive nature of this case study focused on generating detailed descriptions of one student's experiences, and to better understand complexities of chronic illness not easily measureable quantitatively. Likewise, the experiences of our research team, specifically a member whose experiences paralleled our case study, challenged the research team to systematically address potential subjectivity and scrutinize the relational intimacy formed between interviewer and interviewee.

\section{Conclusions and Implications}

A single-case study is primarily exploratory and descriptive in nature, and not intended to discover causal relationships among data generated. However, we believe our findings highlight provocative questions, often philosophical, but with potential to challenge beliefs and practice. When a student has complex medical needs, yet does not qualify for special education services, how is responsibility for deciding appropriate health care in school settings determined? How do schools ensure an adequate exploration of the individual needs is conducted, and an appropriate support plan is developed and monitored for effectiveness? How do schools, health care professionals, and families address communication challenges unique to medical conditions with potential stigma? In light of these uncertainties, we find the questions underlying policy and procedural decisions to be of critical importance for all stakeholders.

School counseling services should be actively involved on teams for all students with chronic illness, even when the students appear outwardly to be handling their condition well. Emily's case is illustrative, as literature shows increased anxiety and depression in children with chronic illness, including those with incontinence. Similar to school nurses, school counselors often have large caseloads. They also may not have extensive training in providing the type of emotional support needed by this population. However, with an awareness that many children with chronic illness have clinically significant anxiety, school mental health professionals can assist in daily 
monitoring of the student's overall social/emotional wellbeing and make referrals for additional assistance when needed.

Educators must ensure that educational plans are individualized, as is required by federal mandates. Students with rare and stigmatizing conditions cannot be adequately served with cookie cutter support plans. They require more frequent monitoring of progress and communication among the student, family, and professionals. When a student misses school as frequently as Emily, more in depth measures should be taken including services such as more extensive homebound services, compensatory schooling in the summer, or the use of virtual schooling in tandem with the regular school year. The proliferation of online programs, particularly for high school, makes this a more accessible option than ever before.

All of these suggestions, however, require coordination. Many schools struggle to provide coordination for students with 504 Plans, as there are no additional funds to support case management for this population. Accommodations provided through Section 504 are the fiscal responsibility of local educational agencies, often causing a burden to rural and underfunded schools. Furthermore, even in states with funding for school nurses and other health professionals, those funds are often woefully inadequate to provide the level of individualized care for students with chronic illness at school.

\section{References}

American School Health Association. (2002). Health care and students with disabilities. Kent, $\mathrm{OH}$ : American School Health Association.

Bai, Y., Zhengwei, Y., Wang, W., Zhao, Y., Wang, H., \& Wang, W. (2000). Quality of life for children with fecal incontinence after surgically corrected anorectal malformation. Journal of Pediatric Surgery, 35(3), 462-464. http://dx.doi.org/10.1016/S00223468(00)90215-X

Baker-Towell, D. M., \& Towell, A. D. (2003). A preliminary investigation into quality of life, psychological distress and social competence in children with cloacal exstrophy. Journal of Urology, 169, 1850-1853. http://dx.doi.org/10.1097/01.ju.0000062480.01456.34

Balfanz, R., \& Byrnes, V. (2012). Chronic absenteeism: Summarizing what we know from nationally available data. Baltimore, MD: Johns Hopkins University Center for Social Organization of Schools.

Baxter, P. \& Jack, S. (2008). Qualitative case study methodology: Study design and implementation for novice researchers. Qualitative Report, 13(4), 544-559.

Best, S. J. (2005). Health impairments and infectious diseases. In S. J. Best, K. W. Heller, \& J. Bigge (Eds.), Teaching individuals with physical or multiple disabilities (5th ed., pp. 5985). Upper Saddle River, NJ: Pearson. 
Bloom, B., Cohen, R., \& Freeman, G. (2011). Summary health statistics for U.S. children: National Health Interview Survey, 2010. Vital Health Statistics 10(250), 1-80.

Botto, L. D., Khoury, M. J., Mastroiacovo, P., Castilla, E. E., Moore, C. A., Skjaerven, R, . . Sumiyoshi, Y. (1997). The spectrum of congenital anomalies of the VATER association: An international study. American Journal of Medical Genetics, 71, 8-15. http://dx.doi.org/10.1002/(SICI)1096-8628(19970711)71:1<8::AID-AJMG2>3.0.CO;2-V

Boyt, M. (2005). Teachers' knowledge of normal and abnormal elimination patterns in elementary school children. Journal of School Nursing, 21(6), 346-349. http://dx.doi.org/10.1177/10598405050210060801

Brandt, M. L., Daigneau, C., Graviss, E. A., Naik-Mathuria, B., Fitch, M. E., \& Washburn, K. K. (2007). Validation of the Baylor Continence in children with anorectal malformations. Journal of Pediatric Surgery, 42, 1015-1021. http://dx.doi.org/10.1016/j.jpedsurg.2007.01.070

Butler, R., \& Swithinbank, L. (2007). Childhood nocturnal enuresis and daytime wetting-A handbook for professionals. Bristol: ERIC.

Caldwell, T. H., Sirvis, B. P., Still, J., Still, M., Schwab, N., Jones, J., . . Appel, S. (1997). Students who require medical technology in school. In S. Porter, M. Hayne, T. Bierle, T. Caldwell, \& J. Palfrey (Eds.), Children and youth assisted by medical technology in educational settings: Guidelines for care. (2nd ed., pp. 3-15). Baltimore: Paul H. Brookes.

Carroll, H. (2010). The effect of pupil absenteeism on literacy and numeracy in the primary school. School Psychology International, 31(2), 115-130. http://dx.doi.org/10.1177/0143034310361674

Clay, D. (2004). Helping schoolchildren with chronic health conditions. A practical guide. New York: Guilford.

Cohen, E., Kuo, D. Z., Agrawal, R., Berry, J. G., Bhagat, S. K. M., Simon, T. D., \& Srivastava, R. (2011). Children with medical complexity: An emerging population for clinical and research initiatives. Pediatrics, $127(3)$, 529-538.

Creswell, J. (2013). Qualitative inquiry and design: Choosing among five approaches. Thousand Oaks, CA: SAGE Publications.

Dowbiggin, I. R. (2009). High anxieties: The social construction of anxiety disorders. Canadian Journal of Psychiatry, 54(7), 429-436.

Fasten, C. (2000). Hirschsprung's disease. Journal of Pediatric Surgery, 35, 1409.

Fereday, J., Kimpton, L., \& Oster, C. (2011). Parents' experiences of managing their child's incontinence at school. Australian and New Zealand Continence Journal, 17(2), 51-56. 
Filce, H. G., \& LaVergne, L. (2011). Educational needs and accommodations for children with bowel and/or bladder dysfunction. Physical Disabilities: Education and Related Services, $30(1), 30-52$.

Fontana, A., \& Frey, J. (2008). From neutral stance to political involvement. In N. Denzin \& Y. Lincoln (Eds.), Collecting and interpreting qualitative materials ( $3^{\text {rd }}$ ed., pp. 115-159). Los Angeles, CA: Sage Publications.

Funakosi, S., Hayashi, J., Kamiyama, T., Ueno, T., Ishii, T., Wada, M., . . Matsuoka, H. (2005). Psychosocial liaison-consultation for the children who have undergone repair of imperforate anus and Hirschsprung disease. Journal of Pediatric Surgery, 40, 1156-1162. http://dx.doi.org/10.1016/j.jpedsurg.2005.03.059

Grano, C., Aminoff, D., Lucidi, F., \& Violani, C. (2012). Long-term disease-specific quality of life in children and adolescent patients with ARM. Journal of Pediatric Surgery, 47, 1317-1322. http://dx.doi.org/10.1016/j.jpedsurg.2012.01.068

Gray, E., Blackinton, J., \& White, G. (2006). Stoma care in the school setting. Journal of School Nursing, 22(2), 74-80. http://dx.doi.org/10.1177/105984050602200203

Hancock, D., \& Algozzine, B. (2011). Doing case study research: A practical guide for beginning researchers. New York, NY: Teachers College Press.

Individuals with Disabilities Education Act Amendments of 1997, Pub. L. No. 105-117, $105^{\text {th }}$ Cong., $1^{\text {st }}$ Sess.

Lichtman, M. (2013). Qualitative research in education: A user's guide ( $3^{\text {rd }}$ ed.). Los Angeles, CA: Sage Publications.

Lopez, W. L., Mullins, L. L., Wolfe-Christensen, C., \& Bourdeau, T. (2008). The relation between parental psychological distress and adolescent anxiety in youths with chronic illnesses: The mediating effect of perceived child vulnerability. Child Health Care, 37, 171-182. http://dx.doi.org/10.1080/02739610802151464

Lundblad, B., Berg, M., \& Hellström, A. L. (2007). Experiences of children treating functional bladder disturbances on schooldays. Journal of Pediatric Urology, 3(3), 189-193. http://dx.doi.org/10.1016/j.jpurol.2006.08.004

Lundblad, B., Hellström, A. L., Berg, M. (2010). Children's experiences of attitudes and rules for going to the toilet in school. Scandinavian Journal of Caring Science, 24(2), 219-223. http://dx.doi.org/10.1111/j.1471-6712.2009.00707.x

Luscombe, F. A. (2000). Health-related quality of life and associated psychosocial factors in irritable bowel syndrome: A review. Quality of Life Research, 9, 161-176. http://dx.doi.org/10.1023/A:1008970312068 
Merriam, S. (1998). Qualitative research and case study applications in education. San Francisco, CA: Jossey-Bass Publishers.

Miles, M. B., Huberman, A. M., \& Saldaña, J. (2014). Qualitative data analysis: A methods sourcebook ( ${ }^{\text {rd }}$ ed.). Los Angeles, CA: SAGE.

Mills, J. L. A. (2007). Long-term bowel function and quality of life in children with Hirschsprung's disease. Journal of Pediatric Surgery, 43, 899-905. http://dx.doi.org/10.1016/j.jpedsurg.2007.12.038

Mukherjee, B., McCauley, E., Hanford, R. B., Aalsma, M., \& Anderson, A. M. (2007). Psychopathology, psychosocial, gender and cognitive outcomes in patients with cloacal exstrophy. Journal of Urology, 178, 630-635. http://dx.doi.org/10.1016/j.juro.2007.03.144

National Association of School Nurses. (2013). Position statement: Individualized healthcare plans. The role of the school nurse. Silver Spring, MD: National Association of School Nurses.

Nisell, M, Öjmyr-Joelsson, M, Frenckner, B., Rydelius, P., \& Christensson, K. (2008). Views on psychosocial functioning: Responses from children with imperforate anus and their parents. Journal of Pediatric Health Care, 22(3), 166-174.

Rittler, M., Paz, J. E., \& Castilla, E. E. (1996). VACTERL association, epidemiologic definition and delineation. American Journal of Medical Genetics, 63, 529-536. http://dx.doi.org/10.1002/(SICI)1096-8628(19960628)63:4<529::AIDAJMG4>3.0.CO;2-J

Saldaña, J. (2013). The coding manual for qualitative researchers ( $2^{\text {nd }}$ ed.). Los Angeles, CA: Sage.

Sato, A. F., Hainsworth, K. R., Khan, K. A., Lanwig, R. J., Weisman, S. J., \& Davies, W. H. (2007). School absenteeism in pediatric chronic pain: Identifying lessons learned from the general school absenteeism literature. Child Health Care, 36(4), 355-372. http://dx.doi.org/10.1080/02739610701601387

Section 504 of the Rehabilitation Act of 1973, 34 C.F.R.

Seidman, I. (2013). Interviewing as qualitative research: A guide for researchers in education and the social sciences ( $4^{\text {th }}$ ed.). New York, NY: Teachers College Press.

Shapiro, B. S., Dinges, D. R., Orne, E. C., Bauer, N., Whitehouse, W. G., Ohene-Frempon, K., \& Orne, M. T. (1995). Home management of sickle cell-related pain in children and adolescents: National history and impact on school attendance. Pain, 61, 139-144. http://dx.doi.org/10.1016/0304-3959(94)00164-A 
Solomon, B. (2011). VACTERL/VATER Association. Orphanet Journal of Rare Diseases, 6, 56. http://dx.doi.org/10.1186/1750-1172-6-56

Solomon, B. D., Pineda-Alvarez, D. E., Raam, M. S., Bous, S. M., Keaton, A. A., Vélez, J. I., \& Cummings, D. A. (2010). Analysis of component findings in 79 patients diagnosed with VACTERL association. American Journal of Medical Genetics, 152A, 2236-2244. http://dx.doi.org/10.1002/ajmg.a.33572

Stake, R. (1995). Qualitative case studies. In N. Denzin \& Y. Lincoln, (Eds.). Strategies of qualitative inquiry ( $3^{\text {rd }}$ ed., pp. 119-149), Los Angeles, CA: Sage.

Stjernqvist, K., \& Kockum, C. C. (1999). Bladder exstrophy: Psychological impact during childhood. Journal of Urology, 162, 2125-2129. http://dx.doi.org/10.1016/S00225347(05)68139-6

Sureshkumar, P., Bower, W., Craig, J. C., \& Knight, J. F. (2003). Treatment of daytime urinary incontinence in children: A systematic review of randomized controlled trials. Journal of Urology, 170(1), 196-200. http://dx.doi.org/10.1097/01.ju.0000072341.34333.43

U.S. Department of Health and Human Services, Health Resources and Services Administration, Maternal and Child Health Bureau. (2013). The national survey of children with special health care needs chartbook 2009-2010. Rockville, MD: U.S. Department of Health and Human Services.

Weaver, A., \& Dobson, P. (2008). Urinary continence difficulties in adolescence. British Journal of School Nursing, 3(4), 186-190. http://dx.doi.org/10.12968/bjsn.2008.3.4.30548

Weaver, D. D., Mapstone, C. L., \& Yu, P. L. (1986). The VATER association. Analysis of 46 patients. American Journal of Diseases of Children, 140, 225-229. http://dx.doi.org/10.1001/archpedi.1986.02140170051027

Wheaton, M. G., Berman, N. C., Franklin, J. C., \& Abramowitz, J. S. (2010). Health anxiety: Latent structure and association with anxiety-related psychological processes in a student sample. Journal of Psychopathology and Behavioral Assessment, 32, 565-574. http://dx.doi.org/10.1007/s10862-010-9179-4

Williams, K., Chambers, M., Logan, S., \& Robinson, D. (1996). Association of common health symptoms with bullying in primary school children. The BMJ, 313, 17-19. http://dx.doi.org/10.1136/bmj.313.7048.17

Wodrich, D. L., \& Cunningham, M. M. (2008). School-based tertiary and targeted interventions for students with chronic medical conditions: Examples from type 1 diabetes mellitus and epilepsy. Psychology in the Schools, 45(1), 52-62. http://dx.doi.org/10.1002/pits.20278

Yi, M. S., Britto, M. T., Sherman, S. N., Moyer, M. S., Cotton, S., Kotagal, U. R., . . Tsevat, J. (2009). Health values in adolescents with or without inflammatory bowel disease. Journal of Pediatrics, 154, 527-534. http://dx.doi.org/10.1016/j.jpeds.2008.10.003 
Yin, R. (2014). Case study design and methods (5 ${ }^{\text {th }}$ ed.). Los Angeles, CA: Sage. 